\title{
ENVIRONMENTAL CARBON FOOTPRINT FROM FLEXIABLE PAVEMENT CONSTRUCTION: A CASE STUDY FROM EGYPT
}

\author{
A. S. Mounir, I. H. Hashim and M. Abdel Shafy. \\ Department of Civil Engineering, Faculty of Engineering, Menoufia University, \\ Shebin El-Kom, Egypt
}

\begin{abstract}
:
Carbon footprint is a term used to describe the total amount of carbon dioxide and other green house gases (GHG) emissions for which an individual/process/organization/activity is responsible. In Egypt, the construction of flexible asphalt pavement has a significant impact on the environment. Therefore; the main objective of this study is to propose a methodology for measuring carbon emissions of asphalt pavement construction using a created model based on Life Cycle Assessment (LCA) as an automatic tool for carbon estimations. The paper reports a case study of GHG emissions from a typical asphalt pavement construction project in Egypt. Field data were analyzed through the created model and the results show that the GHG emissions from the transportation during construction stage are the highest, and account for about $46 \%$ of the total amount. Reduce the transportation distance will help to decrease the GHG emissions. The flexible pavement LCA can help to increase the environmental performance of highways construction and guide decision makers towards road sustainability management.
\end{abstract}

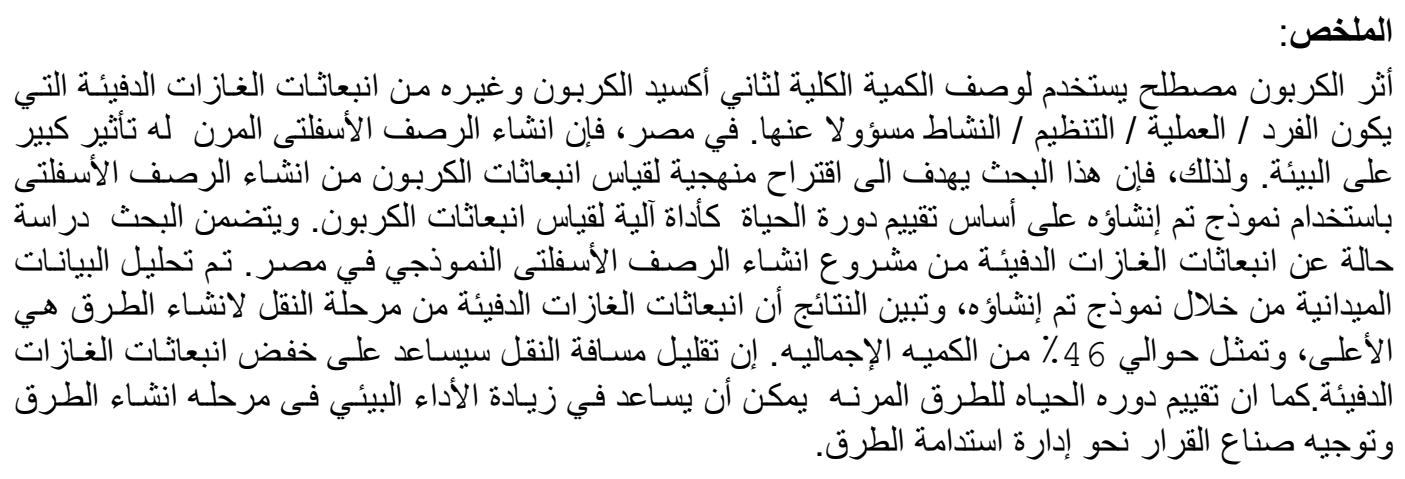

Keywords: Carbon footprint - Green House Gases (GHG) - Asphalt Pavements- Environmental Impacts - Life Cycle Assessment (LCA)

\section{INTRODUCTION}

The highway construction is constantly looking for solutions to improve pavement performance, increase construction efficiency, conserve resources and advance environmental protection. As a result of the continuous increase in the population, economic and social development worldwide, it has become an urgent need for development and increase of road networks. The total length of road networks in Egypt reached to $175000 \mathrm{~km}$ in 2015/2016, as announced by the Central Agency for Public Mobilization and Statistics (CAPMAS). This also led to the diversity and development in the materials and methods used in the construction of road network. Highways construction could cause negative environmental impacts and pollution effects of air, water and soil due to GHG emissions [1]. GHG emissions include carbon dioxide $\left(\mathrm{CO}_{2}\right)$, nitrous oxide $\left(\mathrm{N}_{2} \mathrm{O}\right)$, methane $\left(\mathrm{CH}_{4}\right)$ etc. $\mathrm{GHG}$ emissions are typically measured in terms of carbon dioxide equivalents $\left(\mathrm{CO}_{2} \mathrm{e}\right)$. The two primary types of pavements are flexible and rigid pavements. This study is limited to the flexible pavement alone which is most prevalent in Egypt [2]. Flexible pavement consists of a relatively thin wearing surface of asphalt built over a base course. Base layer course is usually consisting of stone with specified gradation. This layer rest upon a compacted subbase (compacted soil). 
Life Cycle Assessment (LCA) is a technique used to evaluate environmental impacts of a product through all its life cycle stages. It is associated with all the life cycle phases of a product or process, and also includes: raw material extraction, material processing and manufacturing, use, maintenance, repair, and end of life/disposal. LCA as a method can be used to assess the environmental impacts of a road system over its entire life time [3].

LCA studies can help to determine and minimize the energy consumption, use of resources and emissions to the environment by giving a better understanding of the systems. LCAs can also purpose different alternatives for different phases of a life cycle of the system if we have different design alternatives [3]. The life cycle of roads construction are consisting of mainly four major systems (material production, construction, use, and end-of-life) [3]. The paper reports a case study of GHG emissions from a typical asphalt pavement construction project in Bahariya Oasis, western desert, Egypt. The carbon footprints emitted from construction activities consists of three components:

- The emissions from the raw material extraction (Production process).

- The emissions from the transporting materials to the site (Transportations process).

- The emissions from the equipment used during construction (Operating process).

The objective of this paper is to estimate the carbon footprint during asphalt pavement construction of Bahariya Oasis - El Frafra Oasis highway located at the western desert, Egypt, as a case study.

\section{PREVIOUS WORK}

Several previous studies were summarized as in the following substance:

- Butt et al. [1] found that asphalt production and transportation of materials are usually highest in the energy and GHG emissions chain. It is highly favorable to have the quarry site, the asphalt plant and the construction site not far from each other to avoid excess energy use, high economic costs and fuel combustion emissions. It is also highly favorable to use the electricity that has been produced in an efficient way.

- Wang et al. [4] estimated carbon emissions for three types of projects, namely subgrade, pavement, and bridges and tunnels. The boundary comprises raw material production, material transportation, and onsite construction. They derived the material and energy consumption and machine working hours from the budget sheet. However, they did not provide evidence on scope match between emission factors and bill of quantities. For example, material wastes are often incurred on site, but might not be directly calculated in the carbon emission.

- Ma et al. [5] established an inventory analysis method to evaluate the greenhouse gas emissions from Portland cement concrete pavement construction in the west of China. The boundary of the concrete pavement construction process consists of raw material production, concrete manufacture, and pavement onsite construction. However, they failed to provide a transparent method to calculate the quantity of energy and material consumption; this might impede the uptake of this tool in practice.

- Kay et al. [6] reached to GHG emissions in the United States totaled nearly 6.8 billion tons of $\mathrm{CO}_{2}$ equivalents in 2010, of this total, the transportation sector was responsible for more than 1.8 billion tons of emissions, or $27.1 \%$ of total GHG. The transportation sector is the single greatest contributor of $\mathrm{CO}_{2}$ to the earth's atmosphere in the U.S. and accounts for about $31.1 \%$ of all $\mathrm{CO}_{2}$ emissions.

- Zapata et al. [7] studied the energy consumption, environmental impacts of asphalt and reinforced concrete pavement (materials and construction). According to their study, they found that the main consumption of energy from extraction to asphalt placement occurs during the mixing and drying of aggregate $(48 \%)$ for the pavement. Moreover, the production of bitumen accounts for about $40 \%$ of the total energy consumption.

Finally the GHG emissions related to highway construction have attracted the interest of researchers for the last 20 years. All previous LCAs studies have been focused on estimating GHG emissions during various stages of asphalt pavement construction. It was found that materials production and transportation of materials are usually highest in the energy and GHG emissions, therefore the results consistently indicate that an asphalt pavement implies a larger use of energy, which has a negative impact on the environment.

\section{DATA COLLECTION AND ANALYSIS}

The methodology of this study summarized in creating a model based on LCA during the asphalt pavement construction. Data collected from the field during asphalt pavement construction of Bahariya Oasis - El Frafra Oasis highway has been analyzed through the created model. The results were compared with a model prepared by Highway Agency and come out with some conclusions and recommendations for the benefits of decision makers in the future.

\subsection{Case study location}


The road under study links Bahariya oasis by El Frafra oasis in the western desert of Egypt. Fig. 1 illustrates the satellite of the road under study.

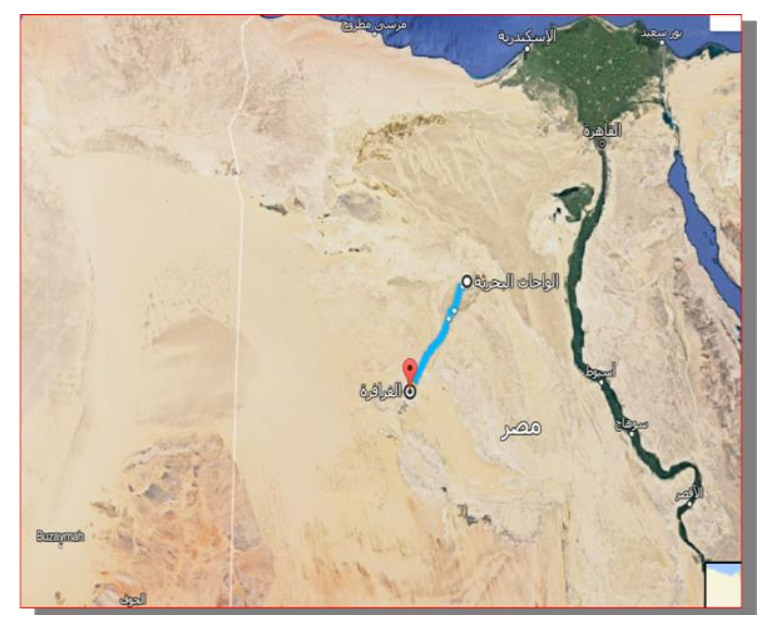

Fig. 1: The satellite image of Bahariya El Frafra road

\subsection{Case study characteristics}

The case study focused on $7.521 \mathrm{~km}$ from 143.521 $\mathrm{km}$ of the total length for asphalt pavement. The coordinates of the road start at $(\mathrm{N} 3134344.6386, \mathrm{E}$ 676898.1431) and ends at $(\mathrm{N}: 3016111.479$, E: $608342.937 \mathrm{~m}$ ). The pavement thickness layers is 11 $\mathrm{cm}$. The width of the asphalt pavement is $11.5 \mathrm{~m}$. The lane width is $3.5 \mathrm{~m}$. The width of the side earth shoulder is $1.5 \mathrm{~m}$., base course on 2- layer with thickness $20 \mathrm{~cm}$ for each and its width is $12.5 \mathrm{~m}$.

Subbase is embankment layers (A-1-a, A-1-b, A-2-4) according to AASHTO (2005) soil classification system [8], slope of earth is $3: 2$; sub grade is stabilized natural ground, side slope is $2 \%$ for drainage. The mixing plant is set up temporarily during the project. The average distance between the asphalt plant and the site is $25 \mathrm{~km}$. Fig. 2 shows layer thickness, Fig. 3 shows typical cross section and Fig. 4 shows the site project picture.

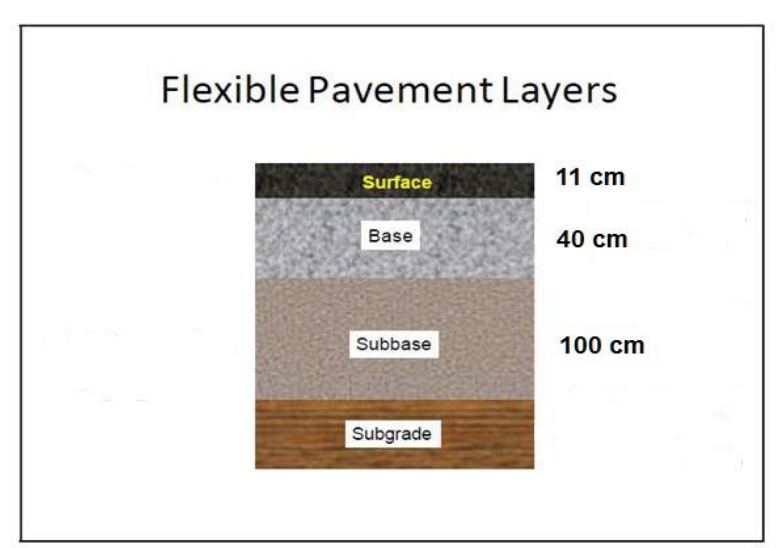

Fig. 2: Layer's thicknesses

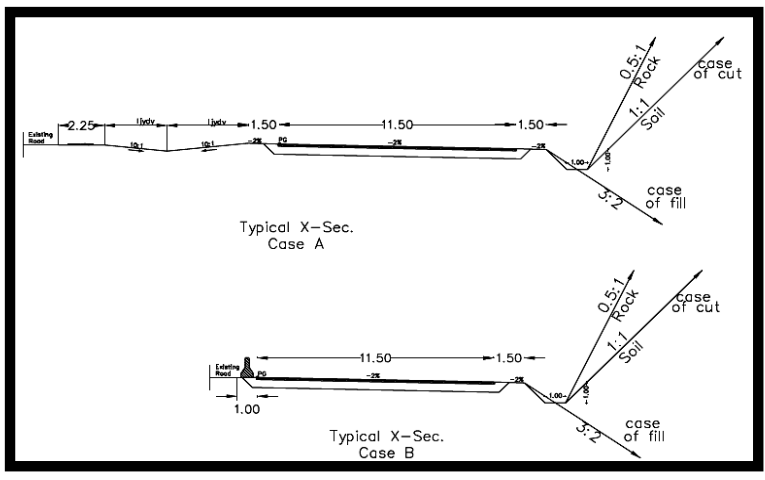

Fig. 3: Typical cross section



Fig. 4: Site project picture

\subsection{Analysis of the data}

A case study of GHG evaluation is provided for the Egyptian asphalt pavement construction project. It comprises of $7.521 \mathrm{~km}$ from $136+000 \mathrm{~km}$ to $143+521$ $\mathrm{km}$. The total paved area is $86500 \mathrm{~m} 2$. Fig. 5 shows the inputs and outputs of the LCA created model used in this study. Inputs include first raw materials used in base, subbase course and asphalt pavement. Second the energy which includes fuel consumption of the equipments such as loader, grader, roller, paver and transportation. Outputs include GHG emissions such as $\mathrm{CO}_{2}, \mathrm{~N}_{2} \mathrm{O}$ and $\mathrm{CH}_{4}$ associated with highway construction.

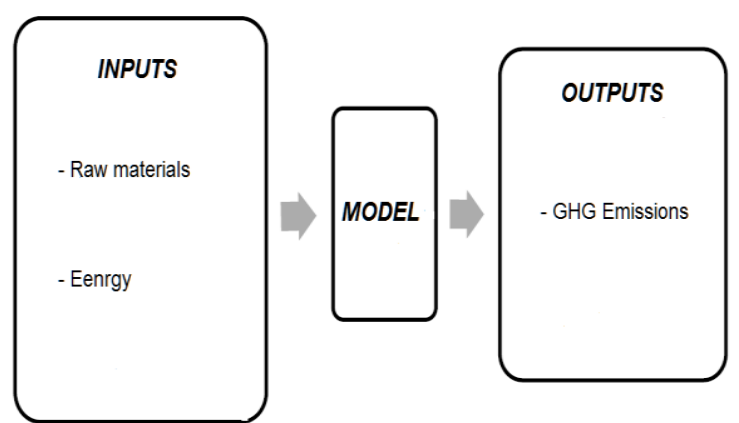

Fig. 5: Main framework of the created model 
The required data were obtained and collected through field data during the work of the project. Then the LCA model was created. Fig. 6 presents the relations between worksheets in the created LCA model of asphalt pavement process as in the following:

- Evaluating of GHG emissions for the raw material production from the crusher and the asphalt plant.

- Evaluating of GHG emissions for transportation process of base / subbase courses and the asphalt pavement.

- Evaluating of GHG emissions for the operating process of base / subbase courses and the asphalt pavement.

Base / subbase courses processes

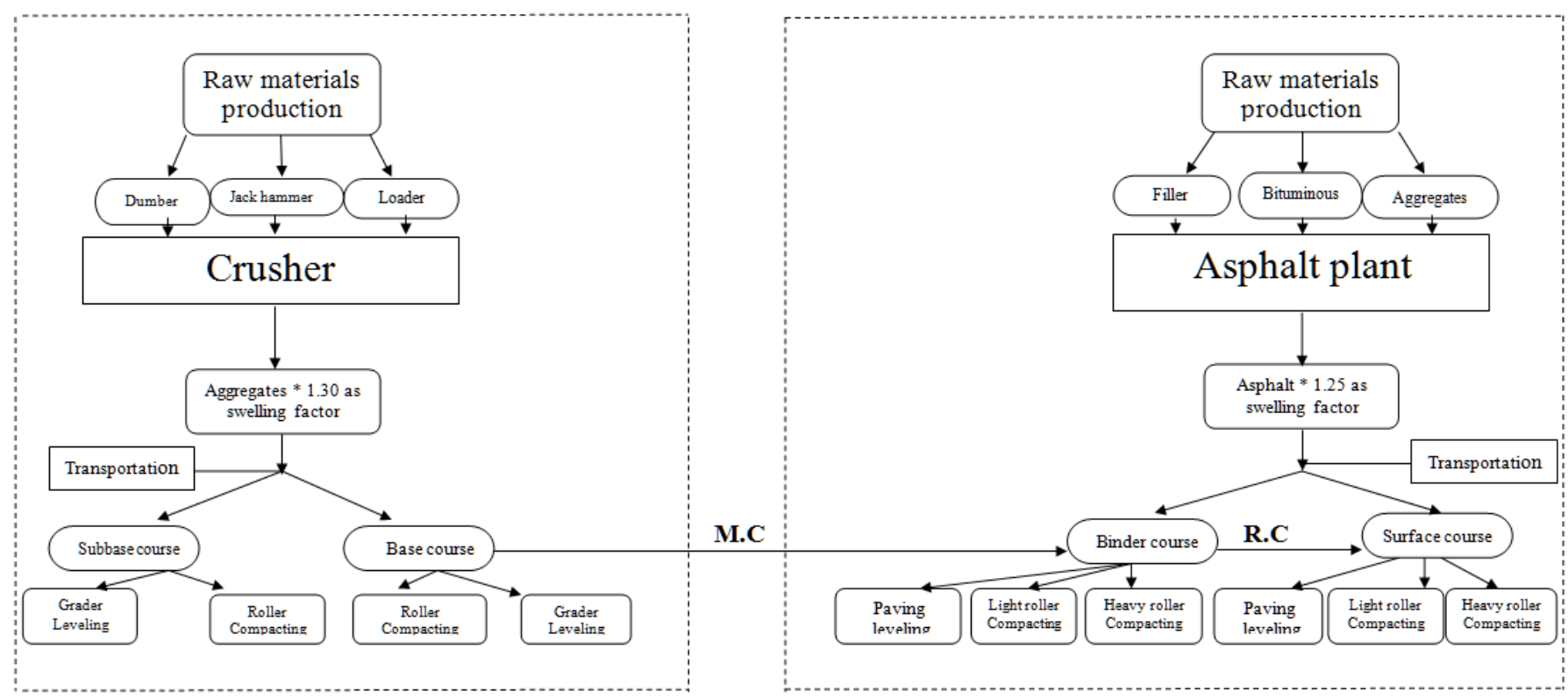

Fig. 6: Relations between worksheets in LCA created model of asphalt pavement process.

Based on the relations of Fig. 6, Table 1 presents the parameters of the created LCA model for the GHG emissions of raw material production from asphalt plant. Therefore GHG emissions equal the fuel consumption (gallon) multiply in emission factor for each gas. Where the fuel consumption (gallon) $=$ fuel consumption $(\mathrm{L}) \times$ solar density $(0.876) \times(0.3108)$, the emission factors for the fuel calculated according to Federal Register, 2010 EPA [10].

Table 1: GHG emissions of raw material production from asphalt plant

\begin{tabular}{|c|c|c|c|c|c|c|c|c|c|c|c|c|c|c|}
\hline Type & $\begin{array}{c}\text { Masses } \\
\text { (Ton) }\end{array}$ & Activity & Machine & $\begin{array}{c}\text { Energy } \\
\text { consumption } \\
\text { (L/1t) }\end{array}$ & $\begin{array}{c}\text { Fuel } \\
\text { consumption } \\
\text { (L) }\end{array}$ & $\begin{array}{c}\text { Fuel } \\
\text { consumption } \\
\text { (kg) }\end{array}$ & $\begin{array}{c}\text { Fuel } \\
\text { consumption } \\
\text { (gallon) }\end{array}$ & $\begin{array}{c}\mathrm{CH}_{4} \\
\text { factor } \\
(\mathrm{g} / \text { gallon })\end{array}$ & $\begin{array}{c}\mathrm{N}_{2} \mathrm{O} \\
\text { factor } \\
(\mathrm{g} / \mathrm{gallon})\end{array}$ & $\begin{array}{c}\mathrm{CO}_{2} \\
\text { factor } \\
(\mathrm{kg} / \mathrm{gallon})\end{array}$ & $\begin{array}{c}\mathrm{CH}_{4} \\
\text { factor } \\
(\mathrm{g})\end{array}$ & $\begin{array}{c}\mathrm{N}_{2} \mathrm{O} \\
\text { factor } \\
(\mathrm{g})\end{array}$ & $\begin{array}{c}\mathrm{CO}_{2} \\
\text { factor } \\
(\mathrm{kg})\end{array}$ & $\begin{array}{c}\mathrm{T}^{\text {Ton }} \\
\mathrm{CO}_{2}\end{array}$ \\
\hline Asphalt & 21882.35 & $\begin{array}{c}\text { Asphalt } \\
\text { plant }\end{array}$ & Plant & 9 & 196941.1455 & 172520.4435 & 53619.35383 & 0.57 & 0.26 & 10.21 & 30563.03 & 13941.03 & 547453.6 & 547.4536 \\
\hline
\end{tabular}




\subsection{Evaluation of GHG emissions from the model}

Most pavement construction activities are carried out with heavy machinery and equipment. The GHG emissions of asphalt pavement consist of those from the machines and equipment used in the construction process. It is calculated by multiplying the energy consumption data (ECD) by the emission factor (EF) of each energy type, fuel or electricity [9], as shown in Equation below, The emission factors for the fuel calculated according to Federal Register, 2010 EPA [10].

The equation is $(\mathrm{GHG})$ emissions $=(\mathrm{ECD}) \times(\mathrm{EF})$.

The created LCA model depends on the Energy consumption method includes the following:

* Evaluating of GHG emissions for the raw material production from the crusher and the asphalt plant.

* Evaluating of GHG emissions for the transportation process of base / subbase courses and the asphalt pavement.

* Evaluating of GHG emissions for operating process of base / subbase courses and the asphalt pavement.

\subsubsection{GHG emissions from raw material production}

For the raw material production, the crusher is used to produce aggregates for base/subbase courses, the asphalt plant is used to produce asphalt for surface and binder courses. The pavement raw material quantities can be calculated from the volume because the quantities are proportional to the cross-section area and length. The density of asphalt mixture is $2.30 \mathrm{t} / \mathrm{m}^{3}$. Based on the geometry of the pavement structure and material density, the total pavement materials quantities are calculated, as follows:

* From the crusher $\quad: 7521 \times 12.5 \times .4 \times 2.24=84235 \mathrm{~T}$

$*$ From the asphalt plant: $7521 \times 11.5 \times .11 \times 2.3=21883 \mathrm{~T}$

Energy consumption for aggregate production includes the rock smashing, quarrying, loading, and hauling, by using jack hummer and loader. To obtain these aggregates which are used in base and subbase courses from the crusher, field data shows that the crusher consumes 1liter solar to produce $1.0 \mathrm{~m}^{3}$ of aggregates, jack hammer consumes 1.0 liter solar to smash $1.0 \mathrm{~m}^{3}$ rocks, loader consumes 1liter solar to load and haul $1.0 \mathrm{~m}^{3}$ of aggregates. Energy consumption of asphalt plant is 9 liter solar to produce 1 ton asphalt [11]. The total GHG emissions of raw material production from the crusher is multiplied by 1.30 as swelling or losing factor due to the ratio of voids, compacted, etc [11]. Also the total GHG emissions of raw material production from asphalt plant is multiplied by 1.25 as swelling or losing factor due to the ratio of voids, compacted, etc[11].
3.4.2 GHG emissions from transportation process of base / subbase courses and the asphalt pavement

For the transportation process of base / subbase courses and the asphalt pavement, field data shows that truck which used at transportation phase consumes 1.6 liter solar / km, medium curing (M.C) tank consumes 65 ton solar to spray the prime coat by rate $1.5 \mathrm{~kg} / \mathrm{m}^{2}$, rapid curing (R.C) tank consumes 12 ton solar to spray the tack coat by rate $0.50 \mathrm{~kg} /$ $\mathrm{m}^{2}[11]$.

3.4.3 GHG emissions from operating process of base / subbase courses and the asphalt pavement

For the operating process of base / subbase courses and the asphalt pavement, field data in table 2 shows that grader motor which used at leveling phase consumes 80 liter solar / $1000 \mathrm{~m}^{2}$, road roller (16 tons) which used at compacting phase consumes 20 liter solar / $1000 \mathrm{~m}^{2}$, that asphalt paver consumes 40 liter solar $/ 1000 \mathrm{~m}^{2}$ for paving phase; heavy vibratory roller \& rubber tire roller and light vibratory roller consume 20 liter solar $/ 1000 \mathrm{~m}^{2}$ for each one that for compacting phase [11].

Table 2: Machinery energy consumption Source:[11]

\begin{tabular}{ll}
\hline Machine & Energy Consumption \\
\hline Grader & 80 liter $/ 1000 \mathrm{~m}^{2}$ (solar) \\
Heavy roller & 20 liter $/ 1000 \mathrm{~m}^{2}$ (solar) \\
Rubber tire roller & 20 liter $/ 1000 \mathrm{~m}^{2}$ (solar) \\
Asphalt paver & 40 liter $/ 1000 \mathrm{~m}^{2}$ (solar) \\
\hline
\end{tabular}

From all data above LCA model was created, GHG emissions equal fuel consumption (gallon) multiply in emission factor for each [9]. Outputs include GHG emissions such as $\mathrm{CO}_{2}, \mathrm{~N}_{2} \mathrm{O}$ and $\mathrm{CH}_{4}$ associated with highway construction. As the values of gases $\mathrm{N}_{2} \mathrm{O}$ and $\mathrm{CH}_{4}$ are very small compared with $\mathrm{CO}_{2}$. So they can be neglected and considers $\mathrm{Co}_{2}$ the main gas of the GHG emissions [10].

\subsection{Evaluating of GHG emissions for pavement} construction process according Highway Agency

The Highways Agency as a Government Agency is committed to contributing to the Government's targets for greenhouse gas (GHG) emissions reductions. In June 2007, the Highways Agency published its first Sustainable Development Action Plan (SDAP) which established the target to investigate the Highways Agency's carbon footprint from construction, maintenance and network operations. A Carbon Calculation Tool has been developed to enable the Highways Agency to identify the emissions baseline associated with the Highways Agency's activities [12]. The Calculation Tool also provides a reporting mechanism for the ongoing 
calculation of carbon and GHG emissions as part of an overall Carbon Management Strategy (CMS). And then the values of base, subbase courses (quarried aggregates) which equals 84225 ton, average distance transport is $25 \mathrm{~km}$, and asphalt mass equals 21883 ton were entered to Highway Agency model.

\section{RESULTS AND DISCUSSION}

For the $7.521 \mathrm{~km}$ long asphalt pavement case study, the total values of GHG emissions for asphalt pavement construction include raw material production, construction process of base / subbase courses and construction process of asphalt are 2213.66 ton $\mathrm{Co}_{2}$ as the table 3 indicates, The total GHG emissions of asphalt construction are shown in Fig. 7. Table 4 indicates the values of $\mathrm{Co}_{2}$ sources from Highway Agency which equaled 2210 ton and the total GHG emissions of asphalt construction shown in Fig. 9.

Table 3: Values of $\mathrm{Co}_{2}$ sources from created model

\begin{tabular}{|c|c|c|}
\hline $\mathrm{CO}_{2}$ Source & $\begin{array}{c}\text { Embodied } \\
\mathrm{CO}_{2} \\
(\mathrm{Ton})\end{array}$ & \% proportion \\
\hline Asphalt & 444.27 & 20.00 \\
\hline Materials & 759.78 & 34.00 \\
\hline Transportation & $1,009.62$ & 46.00 \\
\hline Total & $2,213.66$ & 100.00 \\
\hline
\end{tabular}



Fig. 7: Total GHG emissions of asphalt construction From created model

The $\mathrm{CO}_{2}$ emission of asphalt course is 444.27 ton (20\%) emissions. The $\mathrm{CO}_{2}$ emission of the stabilized aggregate base/subbase course is 759.78 ton (34\%) emissions. The $\mathrm{CO}_{2}$ emission from transportation phase of base / subbase courses and asphalt pavement processes is 1009.62 ton (46\%) emissions. The total GHG emissions of asphalt construction are shown in Fig. 8. It can be seen that transportation phase percent nearly half.
Based on the assumptions of the government policy makers that each ton of $\mathrm{CO}_{2}$ costs $39 \$$ [13]. Then the total price of embodied carbon emissions from the created model $=2213.66$ tons $\times 39 \$=86333 \$$. Hence come the importance of estimation and quantifying GHG emissions such as associated with highways construction.

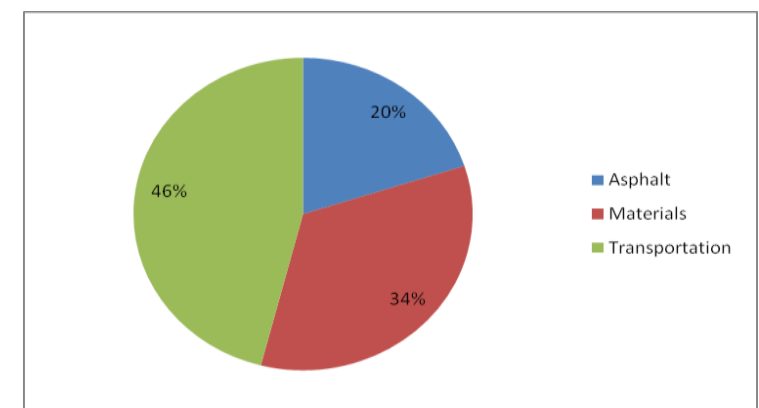

Fig.8: The total GHG emissions of asphalt construction

Table 4: Values of $\mathrm{Co}_{2}$ sources from highway agency

\begin{tabular}{|c|c|c|}
\hline $\mathrm{CO}_{2}$ Source & Tonnes $\mathrm{CO}_{2}$ & \% Proportion \\
\hline Waste & 0 & \\
\hline Transport & 328 & 15 \\
\hline Materials & 1882 & 85 \\
\hline Energy & 0 & \\
\hline TOTAL & 2210 & 100 \\
\hline
\end{tabular}



Fig. 9: Total GHG emissions of asphalt construction From Highway agency

The data collected from the site was analyzed through created model, and the results are compared with the results of highway agency, it's clear that the values are nearly from both. Therefore, in the design of the asphalt pavement construction, the main focus should be the control of energy consumption, the use of energy efficient equipment and the optimization of the construction management. In the design of the stabilized aggregate base/subbase, the main focus 
should be to decrease the GHG emissions from the raw materials production.

The use of high efficiency and energy saving methods of the production and the transportation phases can achieve the purpose of energy saving and emission reduction. The data in this case study were collected from the field projects in Egypt. On the other hand, the fast growth of new built highways in Egypt calls for a bespoke model and robust data to measure and reduce the GHGs from the road sector. The evaluation of GHG emissions due to the highway construction will be a very important area for research in the years to come.

In summary, this whole study provides a deeper insight of including the asphalt pavement construction stage in life cycle assessment of highways. It is expected that there will be a significant amount of change in energy consumption and emissions when a new mechanism of raw materials production is available and the transportation distance are considered during the construction stage.

\section{SUMMARY \& CONCLUSIONS}

The overall aim of this work has been to estimate the environmental carbon footprint associated with highways construction in Egypt. Data were collected from Bahariya - El Frafra highway project. From the detailed analysis of the accumulated data, the following conclusions can be drawn for the research:

1. Asphalt pavement construction has significant environmental impacts. GHG emissions are evaluated and calculated for a case study in Egypt, including raw materials production, transportation, and operating phase. The total $\mathrm{CO}_{2}$ emission of the $7.521 \mathrm{~km}$ long asphalt pavement construction in Bahariya - El Frafra highway project is 2213.66 ton.

2. The total GHG emissions of the asphalt construction, according to the Highway Agency are 2210 ton.

3. The comparison between different models shows that The $\mathrm{CO}_{2}$ emission from transportation phase in of the created model is great compared with the Highway Agency model.

4. It was found transportation phase of base / subbase courses and asphalt pavement processes is the highest in the energy and caused most of the impact, with a contribution to the overall impact. Reduce the transportation distance will help decrease the GHG emissions by using the mobile crusher.
5. LCA is a methodical tool which will be useful to the decision makers in Egypt to improve performance of flexible pavement construction. It is necessary to concern the benefit provided by this kind of models that assessing various types of pavements which is a significant progress over the static. Pavement LCA models also offered the advantage on time and cost effective, extensive skill and proper assignment in performing better pavement LCA.

6. LCA created model which was used for estimating the environmental carbon footprint can be useful for various related studies in order to open the door for this important tool of environmental impact assessment to be applied widely in Egypt and in Africa as well.

\section{RECOMMENDATION}

Though this study successfully accomplished its main goals, there is always room to improve and expand knowledge. The following list contains a number of major recommendations and future research recommendations:

1. It is worth mentioning that the results and relationships presented in this research are a step towards understanding the relation between GHG emissions associated with highway construction and its effect on environmental in Egypt.

2. It is recommended that further research should be conducted in other highways in different Governorates in Egypt to generalize the findings of this study and be capable of estimating the GHG emissions associated with highway constructions.

3. It is recommended that replacing natural aggregates with recycled and secondary in asphalt pavements reduces landfill pressures and quarrying demands, complements other solid waste management efforts in providing an alternative outlet for the waste otherwise destined for landfill. Therefore, GHG emissions due to raw materials production will be reduced. That affects positively on the environment.

4. It is recommended that replacing the static crusher with the mobile crusher which can be useful for reducing the transportation distance.

5. It is recommended that searching for another source of energy alternative to fuel such as electricity for the crusher and the asphalt plant, but it may be not useful as most of the road projects are in the desert. 
6. The developed methodology was conducted to estimate the GHG emissions through production, transportations and operating phases only. So, future research should be carried out to estimate the GHG emissions through all stages of highway constructions (production, transportations, operating, curing, recycling and maintenance)

7. In addition to predicting the pavement life expectancy and the use of the recycled materials which may reduce the GHG emissions from the manufacture process, should be considered at future researches.

\section{REFERENCES}

[1] Butt, A. (2014). "Life Cycle Assessment of Asphalt Roads." PHD, Stockholm, Sweden 14-006 ISBN 978-91-87353-48-2.

[2] Ghazy, M. R. and Abdallah, A. M. (2016)." Life Cycle Assessment of Flexible Pavement Construction." Article no.BJAST.20620.

[3]. ISO 14042. (2006)." Environmental management - Life cycle assessment - Life cycle impact assessment." International Standardisation Organization, Geneva, Switzerland.

[4] Wang, X., Duan, Z., Wu, L. and Yang, D.(2015)."Estimation of Carbon Dioxide Emission in Highway Construction. ", a case study in southwest region of China. J. Clean. Prod., 103, 705-714.

[5] Ma, F., Sha, A., Yang, P. and Huang, Y. (2016)." The Greenhouse Gas Emission from Portland Cement Concrete Pavement Construction." Int. J. Environ. Res. Public Health, China 109, 13, - 632.

[6] Kay, A.I., Noland, R.B.and Rodier, C.J. (2014). "Achieving Reductions in Greenhouse Gases in the US Road Transportation Sector." United States, 69, 536- 545

[7] Zapata, P. and Gambatese, J.A. (2005)." Energy Consumption of Asphalt and Reinforced Concrete Pavement Materials." Journal of Infrastructure Systems, Vol. 11, 9-20.

[8] AASHTO. (2005). "Roadway Lighting Design Guide." American Association of State Highway and Transportation Officials. Washington, DC.

[9] Intergovernmental Panel on Climate Change (IPCC). (2006). "Guidelines for National Greenhouse Gas Inventories." ; Institute for Global Environmental Strategies. Hayama, Japan.

[10] Federal Register, EPA. (2010). "Mandatory Reporting of Greenhouse Gases." Final Rule, 40 CFR. 98, 81- 106.
[11] Arab Contractors Company. Cairo, Egypt. Available: http://www.arabcont.com/

[12] Kerwick, C. (2013)."Carbon Calculation Tool Instruction Manual for Major Projects." Version 5e

[13] World Bank report. (2009). Available: http://databank.worldbank.org/ddp/home.do 